Original Article

\title{
Anthelmintic usage on the Reproductive Parameters in Captive reared Agoutis (Dasyprocta leporina) in Trinidad and Tobago, West Indies
}

\author{
Uso de anti-helmíntico nos parâmetros reprodutivos em cutias criadas em cativeiro \\ (Dasyprocta leporina) em Trinidad e Tobago, Índias Ocidentais
}

Kegan Romelle Jones ${ }^{\mathrm{a}, \mathrm{b} *}$ (1) and Gary Wayne Garcia ${ }^{\mathrm{b}}$ (1)

aUniversity of the West Indies - UWI, Faculty of Medical Sciences - FMS, School of Veterinary Medicine - SVM, Department of Basic Veterinary Sciences - DBVS, Mt. Hope, Trinidad and Tobago

bUniversity of the West Indies - UWI, Faculty of Food and Agriculture - FFA, Department of Food Production - DFP, St. Augustine, Trinidad and Tobago

\begin{abstract}
The agouti (Dasyprocta leporina) is a rodent that is found in the Neo-tropical region. This animal is hunted for its meat but has recently been reared in captivity as a source of meat protein in rural communities. A 20-month experiment was carried out to evaluate the effect of an anthelmintic on the reproductive performance of the agouti (Dasyprocta leporina) reared in captivity. This experiment was conducted in the humid tropics of Trinidad and Tobago. Sixteen animals ( 15 females, 1 male) placed in each of the two treatment groups in a completely randomized study design. In treatment 1 (T1) animals were given subcutaneous injections of Endovet Ces ${ }^{\circledR}$ (Ivermectin/Praziquantel) at $0.2 \mathrm{mg} / \mathrm{kg}$ every three months. Treatment 2 (T2) was the negative control group where animals were not exposed to an anthelmintic. Reproductive data were collected at parturition which included birth weight, litter weight, litter size and gender of offspring. The results showed that there was no statistical difference $(p>0.05)$ between the treatment groups with respect to birth weight, litter weight, litter size and gender. However, agoutis that were dewormed had a higher birth weight (220.24 g vs $209.1 \mathrm{~g}$ ) and litter weight ( $369.8 \mathrm{~g}$ vs $343 \mathrm{~g}$ ). The same values were obtained for the litter size (1.7 vs 1.7 ) and animals that were dewormed had a higher female offspring to male offspring (2.41:1 vs 1.11:1). This experiment demonstrated that the use of an anthelmintic strategically in the management of captive reared agoutis had no statistical effect $(p>0.05)$ on the reproductive parameters. Therefore, these animals can be kept in captive conditions without being dewormed and produce efficiently with proper feeding and housing management.
\end{abstract}

Keywords: Endovet Ces ${ }^{\circledast}$, Ivermectina, Praziquantel, peso ao nascer, peso da ninhada, tamanho da ninhada.

\begin{abstract}
Resumo
A cutia (Dasyprocta leporina) é um roedor que se encontra na região neo-tropical. Esse animal é caçado por sua carne, mas recentemente foi criado em cativeiro como fonte de proteína de carne em comunidades rurais. Um experimento de 20 meses foi realizado para avaliar o efeito de um anti-helmíntico no desempenho reprodutivo de cutias (Dasyprocta leporina) criadas em cativeiro. Esse experimento foi conduzido nos trópicos úmidos de Trinidad e Tobago. Dezesseis animais (15 fêmeas, 1 macho) colocados em cada um dos dois grupos de tratamento em um desenho de estudo completamente randomizado. No tratamento 1 (T1) os animais receberam injeções subcutâneas de Endovet Ces $^{\circledast}$ (Ivermectina / Praziquantel) na dose de $0,2 \mathrm{mg} / \mathrm{kg}$ a cada três meses. O tratamento 2 (T2) foi o grupo de controle negativo onde os animais não foram expostos a um anti-helmíntico. Os dados reprodutivos foram coletados no parto, incluindo peso ao nascer, peso da ninhada, tamanho da ninhada e sexo da prole. Os resultados mostraram que não houve diferença estatística $(p>0,05)$ entre os grupos de tratamento com relação ao peso ao nascer, peso da ninhada, tamanho da ninhada e sexo. No entanto, cutias desparasitadas tiveram maior peso ao nascer (220,24 g vs. 209,1 g) e peso da ninhada (369,8 g vs. $343 \mathrm{~g}$ ). Os mesmos valores foram obtidos para o tamanho da ninhada (1,7 vs. 1,7) e os animais que foram desparasitados tiveram uma prole feminina maior do que a prole masculina (2,41: 1 vs. 1,11: 1$)$. Esse experimento demonstrou que o uso de anti-helmíntico estrategicamente no manejo de cutias criadas em cativeiro não teve efeito estatístico $(p>0,05)$ sobre os parâmetros reprodutivos. Portanto, esses animais podem ser mantidos em cativeiro sem serem vermifugados e produzir de forma eficiente com alimentação adequada e manejo do alojamento.
\end{abstract}

Palavras-chave: Ces $^{\circledR}$ Endovet, Ivermectina, Praziquantel, peso ao nascer, peso da ninhada, tamanho da ninhada.

*e-mail: keganjones11@gmail.com

Received: December 18, 2020 - Accepted: January 26, 2021

This is an Open Access article distributed under the terms of the Creative Commons Attribution License, which permits unrestricted use, distribution, and reproduction in any medium, provided the original work is properly cited. 


\section{Introduction}

The agouti (Dasyprocta leporina) is a rodent belonging to the family Dasyproctidae (Nowak and Walker, 1999) that is found in the Neotropics. The agouti is hunted in the wild and farmers have begun rearing the animals intensively (Brown-Uddenberg et al., 2004). The animal is a source of meat protein for rural villages in this region. This rodent has been classified as micro-livestock (NRC, 1991) or mini-livestock (Hardouin et al., 2003) along with the lappe (Agouti paca), capybara (Hydrochoerus hydrochaeris) and guinea pig (Cavia porcellus). The production of agouti in captivity has two functions. Firstly, it will allow for consumption of the animals which would decrease the hunting pressures in the wild. Secondly, it acts as a source of ex-situ conservation where animals can be released into the wild (Brown-Uddenberg et al., 2004).

Livestock that are present in the Neo-tropics can be grouped based on their origins. The first group are domesticated livestock introduced into the Neo-tropics. These animals include cattle (Bos indicus, Bos taurus), sheep (Ovis aries), goat (Capra hircus), pigs (Sus sucrofa) horses (Equus caballus) and chickens (Gallus domesticus) (Jones and Garcia, 2018a). The animals were brought into the Neo-tropics by Europeans invaders. The second group are domesticated animals that originated in the Neo-tropics. These animals were ducks (Anas platyrhynchos), turkeys (Maelegradis gallipavo), chinchillas (Chinchilla langifera) and South American camelids (Lama gunacoa, Lama glama, Lama pacos, Vicuna vicuna) (Jones and Garcia, 2019). The third group of animals were non-domesticated neo-tropical animals with the potential for domestication. These animals include the agouti (Dasyprocta leporina), lappe (Agouti paca), capybara (Hydrochoerus hydrochaeris), red brocket deer (Mazama americana) and manicou (Didelphis marsupialis insularis) (Jones et al., 2019b).

There are vast amounts of information on the domesticated livestock animals (native and introduced in the Neo-tropics). However, there is a dearth of information on non-domesticated neo-tropical animals such as the agouti. Factors affecting its production must be known if this animal is to be domesticated. In the conceptualization of intensive animal production systems, the biology and reproductive aspects of this animal must be known. Based on their diets these animals have been previously classified as frugivores and herbivores (Garcia et al., 2000; Silvius and Fragoso, 2003; Henry, 1999; Dubost and Henry 2006). Recently, these animals have been reclassified as omnivores due to their eating habits in captive and wild populations (Figueira et al., 2014; Lall et al., 2018; Jones et al., 2019c; Smith and Smith, 2019). Anatomically, the agouti has a large caecum that facilitates fibre digestion and a simple acid pepsin stomach (Garcia et al., 2000).

The agouti produces one to three offspring per parturition throughout the year. Adult animals weigh between $2-4 \mathrm{~kg}$ and take nine months to reach sexual maturity (Guimaraes et al., 1997, 2009). The adult female agouti has an oestrus cycle that ranges from 28 to 31 days (Guimaraes et al., 2011). The gestation period of these animals are 103 days (de Oliviera et al., 2019). There is more information in the literature on the nutrition and reproduction in the agouti in comparison to health management. One of the major threats to livestock production has been parasitic diseases. Currently, limited information is available on the effects of parasites on performance parameters in the agouti. Due to the presence of numerous endoparasites (Griffiths, 1940; Cameron and Reesal, 1951; Lainson et al., 2007; da Silva et al., 2008; Goncalves et al., 2007; Suepaul et al., 2016), investigation of the effects of parasites on performance parameters is warranted.

Recently, endoparasites such as Eimeria spp., Trichuris spp., Strongyoides spp. and Paraspidodera uncinata have been found in the agouti (Jones and Garcia, 2017, 2018b). However, these animals were in excellent body condition (Jones and Garcia, 2018b) and blood parameters were within normal reference values (Jones et al., 2019a). This observation then stimulated research into the effects of endoparasites of captive reared agouti in Trinidad. Recently the effect of an anthelmintic of the growth of the agouti in captivity was done. This research compliments that growth experiment. The objective of this project was to observe the effect of anthelmintic use on reproductive performance of captive reared agoutis.

\section{Methodology}

\subsection{Animal location and housing}

This experiment was carried out at the Neo-tropical/ Wildlife Unit at the University of the West Indies Field Station Farm. The farm is located in Mt. Hope (10³8'16" N and $61^{\circ} 25^{\prime} 41^{\prime \prime} \mathrm{W}$.). The unit has been operational for more than two decades. The building is open sided allowing for natural ventilation. The animal enclosures were cleaned on a daily basis. This unit houses approximately one hundred captive reared agoutis at different physiological states (adult males, adult non-pregnant females, juveniles and pregnant females). Captive reared animals were housed in concrete floor pens as well as in cages. In this experiment animals were kept on the floor pens.

\subsection{Diet of the agouti}

The animals were fed a variety of local fruits and forages which could be found on the premises of the farm. These included; breadfruit (Artocarpus altilis), guavas (Psidium guajava), pumpkins (Cucurbita pepo) and mangoes (Mangifera indica). The agoutis were also supplemented with approximately $200 \mathrm{~g}$ of Rabbit Rations formulated by National Flour Mills ${ }^{\circledR}$ and chicken (Gallus domesticus) eggs daily. Throughout the experiment the agouti was given water ad libitum.

\subsection{Experimental Design}

Thirty healthy multiparous captive reared female agoutis were taken and randomly placed into two groups ( 15 females per group). In each group there was a female to male ratio of 15: 1 (Figure 1). Animals that were chosen had weights ranging from 2.10 to $2.8 \mathrm{~kg}$. Each group of animals were exposed to a different anthelmintic treatment. Animals that 
received Treatment 1 were given a subcutaneous injection with Endovet Ces ${ }^{\circledR}$ (Ivermectin/ Praziquantel) at $0.2 \mathrm{mg}$ / $\mathrm{kg}$. Animals that received Treatment 2 were not given any anthelmintic for the entire experimental period. Female agoutis were then observed for signs of pregnancy which included enlargement of the mammary teats and increase in abdominal size. Once pregnancy was confirmed by physical observation, the females were placed in a separated cage. At parturition, the offsprings' sex, birth weights and litter size were taken. The offspring were kept with their mother for two weeks before the mother was returned to her respective group for breeding. The experiment had a duration of twenty (20) months. It began in May 2018 and concluded in January 2020.

\subsection{Statistical Analysis}

Data was analysed using a completely randomized design with the different treatments using the SPSS (20) one-way ANOVA. A significance level of $p<0.05$ was used throughout the experiment. Comparisons were made between means of various treatment groups.

\section{Results}

Several reproductive parameters were reported in this experiment, these were birth weights, litter weights, litter size and gender of offspring. Throughout the duration of the experiment animals that were exposed to the anthelmintic had twenty-five parturitions $(\mathrm{n}=25)$ whilst animals that were not exposed (Control group) experienced ten parturitions $(\mathrm{n}=10)$. There was no statistical difference $(p>0.05)$ between both treatment groups with respect to birth weights, litter weights, litter size and gender of offspring.

Agoutis treated with the anthelmintic had $220.24 \mathrm{~g}$ as compared to their untreated counterparts that weighed $209.1 \mathrm{~g}$ at birth. The litter weight of animals treated with the anthelmintic was heavier ( $369.8 \mathrm{~g}$ ) as compared to the control group (343g). Similar values were recorded for litter size for the both treatment groups, the litter size was recorded as 1.7 offspring per litter irrespective to the treatment group. Throughout the experiment there were only single and twin births recorded (Figure 2); there were no records of triple and quadruplet births. Offspring from parents treated with anthelmintic had a higher female to male ratio (2.41:1) as compared to the control group (1.11:1) (Table 1).

\section{Discussion}

The aim of this study was to provide pertinent information on the effect of deworming on the reproductive performance of captive reared agoutis in Trinidad and Tobago. Reproductive parameters that were recorded were birth weight, litter weight, litter size and gender of offspring. The birth weight of offspring showed no statistical difference $(p>0.05)$ among treatment groups. The birth weight of animals that were dewormed was slightly heavier (220.2 g) than the control group (209.1 g). Similar birthweights were reported in South America for captive reared agoutis. Pachaly et al. (2001) recorded mean birth weights of $193.2 \mathrm{~g}$. Lower birth weights were reported in Brazil were males weighed $147 \mathrm{~g}$ and females

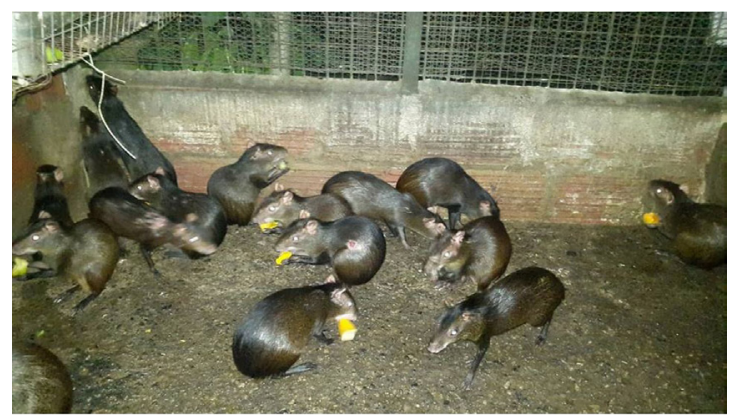

Figure 1. Experimental agouti (Dasyprocta leporina) reared at a female to male ratio of 15:1 on concrete floor pens in Trinidad, West Indies.

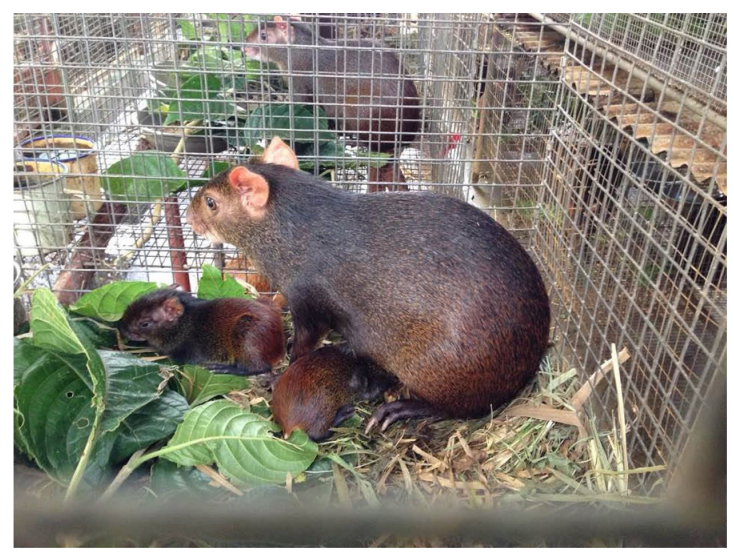

Figure 2. Adult female agouti that produced twin offspring.

Table 1. Effect of Anthelmintic treatment on some reproductive parameters in the Agouti (Dasyprocta leporina).

\begin{tabular}{lccc}
\hline \multicolumn{1}{c}{ Parameters } & Treatment 1 (n=25) (Ivermectin/Praziquantel) & Treatment 2 (n=10) (Control) & P-Value \\
\hline Birth Weight & $220.24 \pm 33.3$ & $209.1 \pm 38.62$ & 0.263 \\
Litter Weight & $369.8 \pm 97.86$ & $343.0 \pm 94.7$ & 0.704 \\
Litter Size & $1.7 \pm 0.47$ & $1.7 \pm 0.46$ & 0.676 \\
Gender (Female: Male) & $1.11: 1$ & $2.4: 1$ & 0.500 \\
\hline
\end{tabular}

$\mathrm{p}$-value of $<0.05$ was considered as significant 
weighed $146 \mathrm{~g}$ (Pachaly et al. 2001) In comparison to this experiment higher birth weights were recorded in Trinidad by Brown-Uddenberg (2001), where male agoutis weighed $307 \mathrm{~g}$ and females had 288g. Differences in the birth weights recorded by several authors can be attributed to the feeding regimes used at the captive sites. Environmental factors can also play a considerable role in the birth weight of offspring.

There were no statistical differences $(p>0.05)$ recorded between treatment group 1 and 2 with respect to litter weight. Agoutis treated with an anthelmintic had heavier litter weights $(369.8 \mathrm{~g}$ ) compared to the control group (343. g). In the literature there has not been published information on the litter weight of the agouti. This parameter is of paramount importance as it can be used in the calculation of the litter weight to the maternal (mothers') body weight. The use of Endovet $\mathrm{Ces}^{\circledR}$ had no statistical effect $(p>0.05)$ on the litter size of the agouti. The average litter size of agoutis in this experiment (both treatment groups) was 1.7. The majority of births were twins with no records of triples or quadruplets. A similar average litter size of 1.71 was recorded in captive reared agoutis in Trinidad (Brown-Uddenberg, 2001). Slightly higher litter sizes of 2.1 and 2.09 were recorded in the Peruvian amazon and Brazil (Mayor et al., 2010; Pachaly et al., 2001).

The sex ratio of the offspring showed no statistical difference $(p>0.05)$ between treatment groups. Agoutis that were dewormed had a female to male ratio of 1.11 to 1 whilst, agoutis in the control group had a higher female to male ratio of 2.4 to 1 . Pachaly et al. (2001) reported a female to male ratio of 1 to 1 which was similar to the agoutis that were exposed to an anthelmintic. The information obtained in this experiment showed that the use of an anthelmintic (Endovet $\mathrm{Ces}^{\circledR}$ ) had no statistical significance on the reproductive performance of captive reared agoutis in Trinidad. Endovet Ces ${ }^{\circledR}$ is a broad spectrum anthelmintic that contains ivermectin and praziquantel.

Similar results were reported on the growth of the agouti, with no statistical significance seen between animals that were dewormed as compared to the control group. Parameters such as dressing percentage, average daily gain and adult body weight were not affected by the use of a dewormer. The results obtained in this experiment were in disagreement to information reported in domesticated livestock species. In cattle, the use of an anthelmintic such as fenbendazole had a positive effect on production. Cattle which were dewormed had higher weight gain as compared to the negative control group in North America (Baltzell et al. 2015). The effects of deworming on reproduction in N'Dama cattle were investigated and annual calving rates were higher for animals treated with fenbendazole as compared to untreated group. It was found that animals should be dewormed twice a year to obtain optimal results (Zinsstag et al., 1997). Anthelminthic usage generally caused increase in growth and reproductive performance in domesticated livestock. Generally, endoparasites remove essential nutrients from its host and by removing these organisms nutrients are utilized by its host for improved performance
Several species of endoparasites have been found in the agouti. However, most investigators reported on the prevalence and presence of the parasites but not the effect the parasites had on the agouti (Griffiths, 1940; Cameron and Reesal, 1951; Goncalves et al., 2007; Lainson et al., 2007; da Silva et al., 2008; Suepaul et al., 2016). In contrast, Jones and Garcia (2017, 2018b) recorded the following parasites and their faecal egg load; Trichuris spp. (2.2 x $10^{2}$ egg per gram), Strongyloides spp. (4.28 x $10^{2}$ egg per gram), Eimeria spp. $\left(2.1 \times 10^{3}\right)$ and Paraspidodera uncinata. These parasites had no effect on the agoutis' body condition (4 out of 5). Agoutis with these parasitic burdens also had haematological and biochemical values that were within the normal ranges for a healthy animal (Jones et al., 2019a).

\section{Conclusion}

This experiment demonstrated that the use of an anthelmintic strategically in the management of captive reared agoutis had no statistical effect on the reproductive parameters. Parameters that were reported for the treatment groups included; birth weight (220.2 g vs 209.1 g), litter weight (369.8 g vs $343 \mathrm{~g}$ ), litter size (1.7 vs 1.7 ) and female to male ratio (1.11: 1 vs $2.41: 1$ ). This proved that parasites present in the gastrointestinal tract had no significant effect on the reproductive parameters of the agouti.

\section{References}

BALTZELL, P., ENGELKEN, T. and O'CONNOR, A.M., 2015. A Critical review and meta-analysis of the magnitude of the effect of anthelminthic use on Stocker Calf production parameters in Northern US. Veterinary Parasitology, vol. 214, no. 1-2, pp. 2-11. http://dx.doi.org/10.1016/j.vetpar.2015.09.019. PMid:26412143.

BROWN-UDDENBERG, R.C., 2001. Conceptualisation of an intensive production model for the agouti (Dasyprocta leporina) a neotropical rodent in Trinidad, West Indies. Kinston, Jamaica: University of the West Indies. MPhil Thesis.

BROWN-UDDENBERG, R., GARCIA, G.W., BAPTISTE, Q.S., COUNAND, T., ADOGWA, A.O. and SAMPSON, T., 2004. The Agouti (Dasyprocta leporina, D. agouti) Booklet and Production Manual. St. Augustine, Trinidad: GWG Publications.

CAMERON, T.W.M. and REESAL, M.R., 1951. Studies on the endoparasitic fauna of Trinidad mammals. Canadian Journal of Zoology, vol. 29, no. 4, pp. 276-289. http://dx.doi.org/10.1139/ z51-025.

DA SILVA, M.K., DA SILVA, A.S., OLIVIERIA, C.M. and MONTIERO, S.G., 2008. Gastrointestinal parasites of the agouti (Dasyprocta leporina). Ciência Animal Brasileira, vol. 9, no. 1, pp. 128-131.

DE OLIVEIRA, G.B., NOBERTO DE ARAÚJO JÚNIOR, H., DOS SANTOS SOUSA, R., VINÍCIUS FERNANDES BEZERRA, F., CESAR DOS SANTOS, A., EDUARDO BEZERRA DE MOURA, C., RODRIGUES SILVA, A., ALEXANDRE DE OLIVEIRA ROCHA, H. and FRANCO DE OLIVEIRA, M., 2019. Morphology of the genital organs of the female red-rumped agouti (Dasyprocta leporina, Linnaeus, 1758) during estrous cycle phases and in advanced pregnancy. Journal of Morphology, vol. 280, no. 8, pp. 1232-1245. http:// dx.doi.org/10.1002/jmor.21027. PMid:31233245.

DUBOST, G. and HENRY, O., 2006. Comparison of Diets of the Acouchy, Agouti and Paca, the Three Largest Terrestrial Rodents 
of French Guianan Forests. Journal of Tropical Ecology, vol. 22, no. 6, pp. 641-651. http://dx.doi.org/10.1017/S0266467406003440.

FIGUEIRA, L., ZUCARATTO, R., PIRES, A.S., CID, B. and FERNANDEZ, F.A.S., 2014. Carrion Consumption by Dasyprocta leporina (Rodentia: Dasyproctidae) and a Review of Meat Use by Agoutis. Brazilian Journal of Biology = Revista Brasileira de Biologia, vol 74, no. 3, pp. 585-587. http://dx.doi.org/10.1590/bjb.2014.0087. PMid:25296206

GARCIA, G.W., BAPTISTE, Q.S., ADOGWA, A.O., KAKUNI, M., ARISHIMA, K. and MAKITA, T., 2000. The Digestive System of the Agouti (Dasyprocta leporina)-Gross Anatomy and Histology. Japanese Journal of Zoo and Wildlife Medicine, vol. 5, no. 1, pp. 55-66. http://dx.doi.org/10.5686/jjzwm.5.55.

GONCALVES, A.Q., PINTO, R.M. and DURETTE-DESSET, M.C., 2007. Parasitism of two zoonotic reservoirs Dasyprocta leporina and Dasyprocta fuliginosa (Rodentia) from the Amazonas with trichostrongylina nematodes (Heligmonellidae): description of a new genus and a new species. Memorias do Instituto Oswaldo Cruz, vol. 102, no. 6, pp. 763-768. http://dx.doi.org/10.1590/ S0074-02762007000600017. PMid:17924008.

GRIFFITHS, H.J., 1940. Studies on Strongyloides agoutii from the agouti (Dasyptocta agouti). Canadian Journal of Research, Section D; Zoological Sciences, vol. 18, no. 5, pp. 173-190. http://dx.doi. org/10.1139/cjr40d-015.

GUIMARAES, D.A., MOREIRA, D. and VALE, W.G., 1997. Determination of Agouti (Dasyprocta leporina) reproductive cycle by coplocytologic techniques. Acta Amazonica, vol. 27, no. 1, pp. 55-64.

GUIMARAES, D.A.A., RAMOS, R.S.L., GARCIA, G.W. and OHASHI, O.M., 2009. The stimulatory effect of male agouti (Dasyprocta prymnolopha) on the onset of female puberty. Acta Amazonica, vol. 39, no. 4, pp. 759-762. http://dx.doi.org/10.1590/S004459672009000400004

GUIMARAES, D.A., OHASHI, O.M., SINGH, M. and VALE, W., 2011. Profile of plasmatic progesterone on pregnancy, and postpartum oestrus of Dasyprocta prymnolopha (Rodentia: dasyproctidae). International Journal of Tropical Biology, vol. 64, no. 4, pp. 1519-1526.

HARDOUIN, J., THYS, E., JOIRIS, V. and FIELDING, D., 2003. Minilivestock breeding with indigenous species in the tropics. Livestock Research for Rural Development, vol. 15, pp. 4.

HENRY, O., 1999. Frugivory and the Importance of Seeds in the Diet of the Orange-Rumped Agouti (Dasyprocta leporina) in French Guiana. Journal of Tropical Ecology, vol. 15, no. 3, pp. 291-300. http://dx.doi.org/10.1017/S0266467499000826.

JONES, K.R. and GARCIA, G.W., 2017. A survey of the gastrointestinal parasites present in the Agouti (Dasyprocta leporina) reared intensively in Trinidad. Livestock Research for Rural Development, vol. 29 , no. 10 , pp. 1-7.

JONES, K.R. and GARCIA, G.W., 2018a. Gastrointestinal parasites of domesticated animals introduced into the Neo-tropics (New World Tropics). Concepts Dairy Vet. Sci., vol. 1, no. 2, pp. 156-186.

JONES, K.R. and GARCIA, G.W., 2018b. Observations on endoparasitic load in captive reared agoutis (Dasyprocta leporina) without anthelmintic exposure in Trinidad, Republic of Trinidad and Tobago. Livestock Research for Rural Development, vol. 30, no. 10, pp. 1-7.
JONES, K.R. and GARCIA, G.W., 2019. Endoparasites of domesticated animals that originated in the neo-tropics (new world tropics). Veterinary Sciences, vol. 6, no. 1, p. 24.

JONES, K.R., LALL, K.R. and GARCIA, G.W., 2019a. Haematological and Serum biochemical values of the agouti (Dasyprocta leporina) reared intensively in Trinidad, Republic of Trinidad and Tobago. Livestock Research for Rural Development, vol. 31, no. 1, pp. 1-8.

JONES, K.R., LALL, K.R. and GARCIA, G.W., 2019b. Omnivorous behaviour of the Agouti (Dasyprocta leporina): A Neo-tropical rodent with the potential for domestication. Scientifica, 2019, pp. 1-5. https://doi.org/10.1155/2019/3759783.

JONES, K.R., LALL, K.R. and GARCIA, G.W., 2019c. Endoparasites of non-domesticated mammals from the Neo-tropics (New World Tropics). Veterinary Sciences, vol. 6, no. 4, pp. 87. http://dx.doi. org/10.3390/vetsci6040087. PMid:31671585.

LAINSON, R., CARNEIRO, L. and SILVEIRA, F.T., 2007. Observations on the Eimeria species of the Dasyprocta leporina (Linnaeus, 1758) (Rodentia: Dasyproctidae) for the state of Para, North Brazil. Memorias do Instituto Oswaldo Cruz, vol. 102, no. 2, pp. 183-189. http://dx.doi.org/10.1590/S0074-02762007005000008. PMid:17426883.

LALL, K.R., JONES, K.R. and GARCIA, G.W., 2018. Nutrition of Six Selected Neo-Tropical Mammals in Trinidad and Tobago with the Potential for Domestication. Veterinary Sciences, vol. 5, no. 2, pp. 52. http://dx.doi.org/10.3390/vetsci5020052. PMid:29757965.

MAYOR, P., BODMER, R. E. and LOPEZ-BEJAR, M., 2010. Functional anatomy of the female genital organs of the wild black agouti (Dasyprocta fuliginosa) female in the Peruvian Amazon. Animal Reproduction Science, vol. 123, no. 3-4, 249-257.

NOWAK, R.M. and WALKER, E.P., 1999. Walker's Mammals of the World. Baltimore: JHU Press, vol. 1.

National Research Council - NRC, 1991. Microlivestock: little-known small animals with a promising economic future. Washington: National Academic Press.

PACHALY, J.R., ACCO, A., LANGE, R.R., NOGUIERA, T.M.R., NOGUIERA, M.F. and CIFFONI, E.M.G., 2001. Order Rodentia (Rodents). In: M.E. FOWLER, Z.S. CUBAS, ed. Biology, medicine and surgery of south American mammals. 2nd ed. Ames, Iowa: Iowa State University Press, pp. 225-237.

SILVIUS, K.M. and FRAGOSO, J.M.V., 2003. Red-Rumped Agouti (Dasyprocta leporina) Home Range Use in an Amazonian Forest: Implications for the Aggregated Distribution of Forest Trees. Biotropica, vol. 35, no. 1, pp. 74-83. http://dx.doi. org/10.1111/j.1744-7429.2003.tb00264.x.

SMITH, R.L. and SMITH, P., 2019. Wild observations of infanticide and cannibalism be Azara's Agouti (Dasyprocta azarae) (Mammalia: Dasyproctidae) in Paraguay. Ethology, vol. 00, pp. 1-5. http:// dx.doi.org/10.1111/eth.12937.

SUEPAUL, R., CHARLES, R. and DZIVA, F., 2016. Aerobic microflora and endoparasites of freshly shot wild Agouti (Dasyprocta leporina) in Trindad, West Indies. Journal of Zoo and Wildlife Medicine, vol. 47, no. 4, pp. 1044-1048. http://dx.doi.org/10.1638/20150055.1. PMid:28080916.

ZINSSTAG, J., ANKERS, P., ITTY, P., NJIE, M., KAUFMANN, J., PANDEY, V.S. and PFISTER, K., 1997. Effect of strategic gastrointestinal nematode control on fertility and mortality of N'Dama cattle in The Gambia. Veterinary Parasitology, vol. 73, no. 1-2, pp. 105-117. http://dx.doi.org/10.1016/S0304-4017(97)80001-5. PMid:9477497. 